\title{
OUT OF THAT HOLE: REFLECTIONS OF THE DEMETRIAN MYTH IN SIX CONTEMPORARY POEMS
}

ABSTRACT. Focusing on the most revisited ancient mother-daughter myth, that of Demeter and Persephone, the paper engages with some of Demetercentered appropriations of the myth in contemporary poetry written by women. Through continual reworkings of the archetypal story about the strongest primary bond between two biologically related females and their forced separation due to male intervention, women poets are increasingly addressing the qualities of Demeter's new-era powers to regain her progeny and restore abundance. While concerned with possibilities of revival and regeneration, contemporary poetic renditions of the mythic framework offer a whole array of plots and images that tend to both perpetuate and challenge original versions of the myth by reassessing the dynamics of mother-daughter disengagement and reunion. The aim of the paper is to examine and juxtapose the strategies of performing the Demeter-Persephone myth in six contemporary Demetrian poems in which their authors extend the mythic space to incorporate other benevolent female characters and their journeys (Fainlight), situate their speakers and Persephones within a national tradition or a familiar setting (Boland), celebrate the birth of a new Persephone (Duffy), embrace the era of contradictions and its impacts on the female body (Ostriker), and fragmenting the myth through the use of various discourses to simulate instant yet profound interplays of deaths and revivals (O'Rourke).

KEYWORDS: Demeter, Persephone, myth, contemporary poetry by women.

1 tatjana.bijelic@flf.unibl.org

This paper was submitted on August 15, 2017 and accepted for publication at the meeting of the Editorial Board held on September 19, 2017. 
In her deeply influential of Woman Born, recognised by generations of scholars as a profound exploration into mythic and realistic aspects of matrilineality, Adrienne Rich invokes the Demeter-Persephone (Ceres-Kore) myth along with the ancient Eleusinian mystery rites that were "the most forbidden and secret of classical civilization, never acted on the stage" (Rich, 1977, p. 240). The myth of the two goddesses who were not antagonistic to each other, but formed a strong mother-daughter bond despite persistent male interventions meant to disrupt and sever female solidarity, serves as a foundation of modern and contemporary matrilineal narratives. The remarkable story of Demeter, the goddess of agriculture and vegetation, whose generosity towards people ceased once her daughter Persephone was abducted by Hades, the god of the underworld, in collaboration with her father Zeus, which consequently transformed her into "Demeter the blighter" (Enemark, 2012, p. 123), continues to haunt writers and researchers who acknowledge the significance of ancient myths, legends, and archetypal accounts in redefining contemporary human relations. While in the past "myths voiced embodied emotions, calmed conflictive thoughts, and gave communal societies opportunity to make sense of suffering" (Norton, 2016, p. 1), today's feminine rewriting of myths, or myth re-visionism, is agreeably viewed as "an act of survival" (Rich, 1995, p. 35) as well as "instructions for survival" based on "retrieved images of what women have collectively and historically suffered" (Ostriker, 1986, p. 215). The need to draw upon ancient mythology in general and the most authentic mother-daughter myth in particular stems from the urge to reconnect with suppressed and long-neglected female heritage. Old stories are sought and restored not only to reclaim the classical tradition, but to respond to it through diverse appropriations of existing myths and legends. For that reason, "women authors since the middle of the twentieth century have claimed classical literature as their own" (Theodorakopoulos, 2012, p. 161), engaging with it from their own past and present experiences. In the process of revising the myth that is crucial for cultural redefinitions and their own creative expression, women writers and poets have evoked the moments of Demeter-Persephone's dyadic bliss, Demeter's divine powers and nurturing/punishing duality, and Persephone's forced sojourn in hell, discussing and reworking the themes of their union, separation and reunion, becoming aware that "the mother-daughter narrative is resolved through continued opposition, interruption, and contradic- 
tion (Hirsch, 1989, p. 35). They have likewise lingered on the motif of pomegranate seeds, challenging its underworld strength to unite the god of the dead and Persephone, his resisting bride. The plight of wise and all-powerful Demeter continues to lure authors into manifold rewritings, and the presumably oldest myth of mother and daughter retains its significance for contemporary women and their fragmented identities. Besides celebrating the earliest female bond with mother, the myth evokes and examines both Hades' rape of Persephone supported by patriarchal social structures, and "the collaboration and friendships between women and goddesses" (House, 2014, p. 62).

Speaking through the characters of the Demeter and Persephone, a number of contemporary British, Irish, and American poets, such as Ruth Fainlight, Eavan Boland, Carol Ann Duffy, Alicia Ostriker, and Meghan O'Rourke, have voiced their and their female contemporaries' concerns within modern mother-daughter relationships, in which the abduction of Persephone may not be perceived as an essential mother-daughter tragedy, but a path to the daughter's individuation and autonomy. On the other hand, the abduction itself may not usurp the central part of the motherdaughter story, but can be put aside as a peripheral episode, or even an insignificant detail in women's relations. In the lines that follow, I will try to illustrate some of the features of contemporary appropriations of the myth, attempting to locate the transference of Demeter's power from purely divine and all-powerful to humanlike and everyday, as well as the somewhat precarious position of the female body in contemporary rites of regeneration.

In her relatively long narrative poem "Pomegranate", Ruth Fainlight (1997) offers an unusual and layered reworking of the Demeter-Persephone story. While the myth's poetic appropriations traditionally address the dynamics of presences and absences in the lives of two biologically bonded women, normally mother and daughter, Fainlight extends the mythic space by adding a woman speaker who at the same time plays the role of a detached narrator and closely participates in the account that is both reworking of the myth and her own life journey comprised of departures and returns. The speaker is also the first to consume a pomegranate fruit and have the seemingly exclusive privilege of knowing its symbolism and experiencing its primeval residues and contemporary power. 
The poem opens with the description of the speaker relishing in the fruit whose "twisted stem is rough as hessian twine" (Fainlight, 1997, p. 12), while her acute senses are visibly sharpened by the pomegranate's peculiar skin, its form, colour, and crystalline texture. The initial emphasis on the fruit's twisting and twining evokes a story of the two inseparable sisters, Luisa and Catalina, who the speaker used to visit decades ago to have her clothes tailored and made. Journeying back from London to the same Spanish-speaking place and the sisters' garden full of lemons and pomegranates, the speaker reminisces about their past encounters, drawing parallels between the actual fruit and its mythic significance within the most revisited account of mother-daughter bonding. Observing that "Persephone and Pluto and Demeter / were names unknown to the sisters" (Fainlight, 1997, p. 12), the speaker is nevertheless fascinated by how the very myth reproduces itself within some less familiar surroundings, where the plot offers modified versions of the place-specific namings and characters: "but they told me of their mother's death/and gave me pomegranates, saying, / 'If you eat one, we shall meet again"' (Fainlight, 1997, p. 12). Even though the sisters are unaware of the myth and its implications, they are experiencing their own version of mother-daughter separation that focuses on the spatial reversal of roles. Namely, the pomegranate garden belongs to the sisters and not to some ominous external forces, and it is the mother who leaves for the underworld, while the daughters stay at home, forming yet another mother-daughter bond, this time with the speaker, through their exclusive ownership of pomegranate seeds. Excluding the male abductors from the sisters' unconscious performance of Demeter-Persephone myth, Ruth Fainlight seems to challenge the long tradition of mythic representation of men controlling women through the use of dominant masculine power and instruments of subjugation. Her Persephones have an ever-present mother and after her death they mother each other and are mothered and daughtered by the speaker. What is more problematised in relation to the daughters' existence is the fact that, due to modernisation of their small town landscape and the new construction sites, their orchard is visibly shrinking, which perhaps signifies the culture-nature divide that threatens to annihilate Persephones' living space. While the sisters, portrayed as the "withered convent girls" (Fainlight, 1997, p. 13) do not attribute the gradual loss of possessions and their own decline to the ruthless forces of patriarchy, Fainlight eventually places 
their story within a more familiar mythic environment governed by a male ruler. The English speaker promises to meet her Spanish sisters again, but concludes for herself that the true recognition of each other will not happen "[u]ntil we meet in Pluto's realm / to share our pomegranate seeds" (Fainlight, 1997, p. 15). Although Luisa and Catalina would not understand the final message, there is something sinister in connecting the potential erasure of their garden to the finality of Pluto's realm. However, whilst it might seem that the sisters are doomed to experience the eternal darkness of enslavement in the underworld, the speaker's presence and "shar[ing] our pomegranate seeds" anticipate a new survival strategy of linking and solidarity that carries a possibility of resurrection.

Although Fainlight's strong delineation of otherness in her depiction of the speaker's encounter with the otherworldly sisters tends to exoticise Persephones' unchanging gestures and body language, along with their mythic orchard and omnipotent pomegranates, the poet ascribes equal significance to their different ways of gaining and expressing wisdom. The speaker's reception of the world through mythology as part of formal education is juxtaposed with the sisters' "other knowledge just as ancient" (Fainlight, 1997, p. 14), which is the empirical knowing of natural laws and lunar phases. On her journey back home, the speaker muses about the timelessness of the sisters' appearance and performs her own appropriation of the pomegranate fruit. While the traditional mythic fruit might denote a reverse original sin and a woman's failure to resist temptation, the sisters' pomegranate seeds are what constitute their entwined feminine identities. By naming the fruit "an archaic bomb", the speaker claims to have successfully exhumed it, together with fresh insights into the foreignness of the sisters who are now "[s]tranger yet closer" (Fainlight, 1997, p. 15). The strong feeling of oneness with the other is achieved through acknowledging the possibility of the women's mutual perceptions of each other as both different and similar, along with the acceptance of manifold rituals whose sources are divergent in their familiarity.

In a continual conversation with her national poetic history, bardic heritage and mythology, Eavan Boland $(1995,2008)$ revises Irish literary canon by challenging its male-dominated foundations. Addressing the long history of women's merely emblematic representations in literature and their exclusion from Irish reading lists, Boland connects the discourse of past exclusions and invisibil- 
ities with contemporary renditions of mother-daughter images. Through her Demeter-Persephone poems, she questions the power of the ancient myth to represent and negotiate her and other women's positions in an era where the separation between mother and daughter is not just antonymous with their life together, but a vital component of their everyday encounters. Her poem "The Making of an Irish Goddess" (Boland, 2008, pp. 178-179), in which the speaker draws parallels between Demeter (Ceres) in hell and herself in her own place of residence stands as a bridge between Demeter's long lost certainties and the poetic subject's unending explorations of the possibility of certainties within a space that houses multiplicities rather than binaries. Ceres is depicted as a witness of her unchanging environment, so that when she looks back on her way to the underworld to search for her daughter, she sees "the same distance in the usual light" stretching across "a seasonless, unscarred earth" (Boland, 2008, p. 178). While the authentic landscape of the ancient myth does not necessarily contradict the speaker's environment, it is the introduction of the contemporary geography of layered human heritage, relativity and uncertainty that distinguishes the rather simplified mythic archetype of Ceres from the geopolitically contextualized poetic subject. While ahistorical Ceres descends to hell "with no sense of time" (Boland, 2008, p. 178), Boland's speaker readily disidentifies from the familiar portrait of the mythic figure, offering her own realistic and more complex version of Demeter:

\section{But I need time -}

my flesh and that history -

to make the same descent. (Boland, 2008, p. 179)

The poetic subject's contemporary geography obviously combines the ancient projections of the landscape with historical palimpsests of places and female bodies through which she constructs a powerful composite of spatial, temporal, and corporeal elements of Demeter-Persephone myth from a strongly empirical position. The very experience of living in a suburb in Dublin, "at the foothills of the Dublin mountains / across which the lights have changed all day" (Boland, 2008, p. 179) points at the changeability of representation that goes in line with the poet's tendency to "transform [the place], not just catalogue it" (Boland and Schmidt, 2001, 3 ). Boland's revision of the myth thus involves not only a fixed depiction of a particular place, "but the sort of bodily knowledge 
[she gets] from the place" (Boland and Schmidt, 2001, 3). The barren land of the myth is likewise appropriated to denote the speaker's own bodily decline amidst its long-repeated gestures and unhealed scars. The agony of the flesh-and-blood woman whose bodily pain reiterates Demeter's mythical loss extends to incorporate numerous generations of mothers and their devoured children, who altogether eventually end up in hell. Although she is positioned to bear the heavy burden of the myth's continuing performances through centuries, the speaker is aware of its specific and painful incarnation in her own historical contexts, claiming that "myth is the wound we leave / in the time we have" (Boland, 2008, p. 179). The wound also embraces the lost and found Persephone, whose contemporary embodiment in the speaker's daughter continues to haunt her searching mother in a rather unexpected way. While observing the changing suburban lights, the Ceres of Dublin is

\author{
holding up my hand, \\ sickle-shaped, to my eyes \\ to pick out \\ my own daughter from \\ all the other children in the distance; \\ her back turned to me. (Boland, 2008, p. 179)
}

The mother's limited vision and unreliable perception of her surroundings is what characterizes Boland's contemporary Demeter as a fragmented imago of the once all-powerful goddess and her divine powers to transform the world for the sake of retrieving her forcibly abducted Persephone. The speaker as Ceres, or rather as an ordinary present-moment Irish mother, seems to be defeated not solely because of external forces that separate her from her daughter, but mostly because of the daughter's own unwillingness to face the mother once she is singled out among other children. While Boland offers a fairly clear juxtaposition of Demeter's past and present incarnations, she avoids giving a more suggestive closure of the poem. The effective open-ended line, "her back turned to me", presupposes many unresolved issues in the mother-daughter relationship. Here arises the question of the possibility of salvation: does Persephone refuse to be saved from hell by her now disoriented mother, or is she utterly unaware of her mother's presence? Pictured as passive and unresponsive, does the daughter keep silent for a particular reason, or is she rejecting the mother alto- 
gether? While these and similar dilemmas invoked by the poem's ending prompt us to consider wider psychological and social issues that leave the mother-daughter chasm open to multifarious commentaries of the mother's eventual defeat, the inevitability of Demeter-Persephone partial detachment appears to be more assertively defined in Boland's another Demeter poem, "The Pomegranate".

Commencing the poem with a stark confession that the motherdaughter myth is "[ $t]$ he only legend I have ever loved", Boland (2008, p. 215) once again combines female mythical legacy with her own experiences of being a woman. The poem is structured around the speaker's rendition of the only familiar myth with which she feels completely at ease since it has spoken to her and her female condition. The fact that the myth serves as a starting point for understanding the plight of generations of women within their specific cultures and historical backgrounds is further supported by evoking the moments of the poetic subject's and the poet's own personal history and her playing the roles of both Ceres and Persephone. Whereas the Persephone phase obviously refers to Boland's early days in London (Boland, 1995, pp. 36-38) as "a city of fogs and strange consonants", where she was "an exiled child in the crackling dusk of / the underworld" (Boland, 2008, p. 215), the phase of Demeter focuses on the speaker's daughter and her inability to anticipate the challenges awaiting her once she enters her own DemeterPersephone cycle. The speaker as Ceres emphasizes her deep insights into seasonal changes and her own seasoning that encompasses both her accumulated wisdom and the daughter's growing up. Loosely following the structure of the previous Boland's poem, "The Pomegranate" gradually flows from the purely mythic space into everyday projections and performances of the myth. The shortest line in the poem, "It is winter" (Boland, 2008, p. 215), can thus be perceived as a subtle turning point from Demeter's selfcenteredness to her preoccupation with Persephone. Ceres assumes the form of an ordinary woman in a contemporary setting, a mother who climbs the stairs to observe her daughter asleep. The stillness of the scene, which Boland experiences as "the disorganization of the beloved moment" (Boland and Schmidt, 2001, p. 5), is interrupted by the mother's shocking revelation that the "uncut fruit" placed next to her daughter's teen magazines and a can of Coke is, in fact, "[t]he pomegranate" itself, the fruit that heralds the daughter's entrance into adulthood. The mother as the contempo- 
rary embodiment of Demeter remembers ancient implications of the pomegranate and attempts to define its significance in relation to the daughter who is yet to experience the legend's forces of separation and recognition. Although the speaker is given the ability to see the imminent threat of separation before it actually happens, she seems reconciled with the inevitability of the daughter's perpetuation of the only viable female myth:

The legend will be hers as well as mine.

She will enter it. As I have.

She will wake up. She will hold

The papery flushed skin in her hand.

And to her lips. I will say nothing. (Boland, 2008, p. 216)

Boland's 1990s representations of the mythic underworld that separates mother and daughter are tailored to fit her and other women's average experiences of fragmented womanhood in familiar (sub)urban spaces crammed with "cars and cable television" (Boland, 2008, p. 216). While in "The Making of an Irish Goddess" the underworld is situated almost within the walking distance, if you are from Dublin or any other modern city, the underworld in "The Pomegranate" is only anticipated through the mother's knowledge of relevant mythology and symbolism. In both poems the mother is aware of her incapacity to save the daughter's from repeating the stumbling fall into her own Ceres-Persephone legendary hell, though the latter poem expresses more profound understanding and acceptance of Persephone's own need to reiterate the patterns of Demeter's seasoning. An important thing to consider here is the amount of power exercised by the speaker. In comparison to the ancient goddess whose divine powers manipulate nature and vegetation, contemporary Demeter/Ceres appears to be losing her cravings for revenge, preferring to be either more practical or philosophical, or wishing to resign altogether, letting her somewhat indifferent Persephone chase her own paths and dreams. In other words, she can neither make Persephone look back at her, nor can she keep her locked in the suburban house as the embodiment of a primary mother-daughter dyad or a single perpetual season.

Frequent reappearances of Demeter and Persephone figures in contemporary poetry by women who explore female literary traditions and motherlines prove that poets have never stopped resurrecting the fundamental mother-daughter myth, appropriat- 
ing it to their own poetics, personal issues and wider cultural contexts. Although contemporary Demeter might seem divested of her supernatural powers and, therefore, of her social position and agency, it is important to understand how contemporary authors tend to poeticize her historical evolution from an enraged and revengeful yet generous goddess to a wise mortal woman who has renounced her dangerous powers for the betterment of her Persephone. However, that the past and present Demeters are not so dramatically different is well-illustrated in Carol Ann Duffy's much praised, revisionist and assertive poetry collection The World's Wife (2001), in which the poet casts a different light on the lives of a number of historically famous men through superimposing the stories of their neglected wives. The collection of subversive dramatic monologues thus contains provocative accounts narrated by Mrs Midas, Mrs Aesop, Mrs Darwin, and Mrs Sisyphus, among the others that range from the voice of Little Red-Cap strengthened by her motherline heritage to the voice of Demeter, whose existence in such an empowering collection promises her newly regained powers. However, unlike Boland's Demeters, who descend to hell with a heavy burden of previous incarnations, or recollect the tragedy of their own exile, both in hope to rescue their Persephones, Duffy's brokenhearted Demeter sits resignedly in her "cold stone room" (Duffy, 2001, p. 76) during one of the harshest winters of her life. The whole atmosphere of sadness changes almost abruptly in the third stanza of the sonnet due to Persephone's solemn arrival that culminates in her "bringing all spring's flowers / to her mother's house" (Duffy, 2001, p. 76). Whilst the mothers in the previous two poems fight hard to reconnect with their daughters, or at least accept their own disturbing insights into the reality of their position, Duffy's Demeter shows no intention of leaving her room encased in ice. Moreover, she seems imprisoned by the forces of nature she is supposed to govern. The change of seasons is out of her control as well as the exact moment of Persephone coming from a far-away land. Noticing Persephone, Demeter "swear $[s] /$ the air softened and warmed as she moved" (Duffy, 2001, p. 76), which additionally indicates that some other powers, not Demeter's, lie behind the arrival of spring. It is also interesting to note that the coming of Persephone is not necessarily her return, but rather her illumination of Demeter's life, or a kind of mother-daughter mutual transformation that might not be interrupted by yet another quickly coming winter. The "Demeter" sonnet might thus imply that 
Demeter is expecting a baby Persephone rather than the daughter who already spent some time in hell. If the myth is appropriated to indicate Persephone's birth, literally or symbolically, along with Demeter's solemn patience that envisions new beginnings and a fresh approach to the ancient bond, it is clear that contemporary Demeter is not powerless, but rather engaged in enacting various aspects of mothering. Positioned as the final poem in the groundbreaking The World's Wife, "Demeter" gives the whole book a powerful closure and a sense of continuing motherlines.

More than two decades after the publication of her seminal Stealing the Language, Alicia Ostriker (2009) contributes to the DemeterPersephone poetry corpus with her own noteworthy poem on mother-daughter reunion. Similar to Duffy's "Demeter" in its brevity of expression and the coming of spring epiphany, Ostriker's "Demeter to Persephone" (Ostriker, 2009, p. 33) offers a completely different reenactment of Persephone's appearance in front of her mother. Whereas Duffy's Demeter celebrates the uniqueness and innocence of her long-awaited daughter whose "small shy mouth" reflects that of the "new moon['s]" (Duffy, 2001, p. 76), Demeter in Ostriker addresses her Persephone directly and in a rather harsh way through a sequence of naturalistic images. Retelling her matter-of-fact story to Persephone, Demeter acknowledges her daughter's return from the very beginning, but the first one-line stanza, "I watched you walking up out of that hole" (Ostriker, 2009, p. 33), anticipates a well-known scenario of the daughter dragging herself out of some familiar underworld in order to meet her mother who is used to the ritual of reencountering Persephone after her victimization or debauchery in hell. The arrival of springtime is embodied in the "rain beating down making puddles in the mud / hissing down on rocks from a sky enraged" (Ostriker, 2009, p. 33), predicting a disharmonious reunion in which the daughter's homecoming is marked by a stark contrast between her quick transformation or changeability and Demeter's integrity and stability: "I waited and was patient / finally you emerged and were immediately soaked" (Ostriker, 2009, p. 33). The nature that accompanies the daughter's return in an unusual manner, through sound and fury, does not seem to respond exclusively to the reunion itself, but is rather in congruence with Persephone's worn-out body and indifferent state of mind:

you stared at me without love in your large eyes that were filled with black sex and white powder 
but this is what I expected when I embraced you

Your firm little breasts against my amplitude (Ostriker, 2009, p. 33)

It is evident that with fully aware Demeter and almost unconscious Persephone the seasonal meeting and love between mother and daughter is not quite reciprocated. Only when Demeter tells Persephone to "get in the car" and she obeys, does the ancient notion of reunion rings true. Prior to the reconnection in the closed space of the car that provides protection from the protesting nature, Demeter does everything to regain her daughter by relativizing and minimizing the consequences of Persephone's (un)willing promiscuity. She cleanses the daughter with the strength of her love, embracing whatever threatens to disfigure and abuse her young body in the cruel underworld, or an equally antagonistic upperworld.

A whole spectrum of convoluted mother-daughter separations and reconciliations in contemporary poetry by women compromise the omnipotence of mythic Demeter to reward and punish her community for the loss of Persephone. However, the present-day Demeter has inherited her predecessor's stamina to regenerate and preserve her motherline in spite of the indisputable lack of communication with her ostensibly dispirited and disoriented newage Persephone. The strong primary bond implied by the myth has created a solid base for obtaining women's subjectivity, which is acknowledged by the contemporary mother saviour who retains her ability to envisage certain natural changes as well as the social trends in which she will fully participate. Her intention is not to conquer and dominate, but to remain proactive and assertive while negotiating with the external forces she cannot control. It can be argued that this shift in Demeter's position is well-represented in the poems by Fainlight, Boland, Duffy, and Ostriker, and even more augmented in Meghan O'Rourke's recent reworking of the myth in which Persephone's abstract position paradoxically becomes more concrete and intangible than ever.

Unlike the previous poems, which tend to follow the linearity (and circularity) of the ancient myth by telling a more or less coherent narrative, O'Rourke's “Demeter in Paris" (O'Rourke, 2013, p. 1) offers a seemingly fragmented reworking of mother-daughter bond that resists traditionally imposed female goodbyes and embraces new forevers that were in the past reserved for men. Structurally presented as a sequence of loosely interrelated affirmative sentences, the poem is a reservoir of proverbial wise thoughts 
(e.g. The absent will only be absent when they're forgotten), aphorisms (e.g. Sometimes I want to be famous once more and then I think about the paparazzi), and literary / artistic allusions (e. g. Henry Miller told Anaïs Nin that the only real death is being dead while alive). While the first part of the poem is particularly abstract and seemingly disconnected from the myth itself, the turning point in the midst of the contemplation on forgetting versus remembering, solitude versus loneliness, and life versus art, introduces Persephone who is equally present and absent: "When I miss my daughter, it's a kind of idea. Then she comes to me unexpectedly" (O'Rourke, 2013, p. 1). According to O'Rourke, presence and absence, as long as they are remembered, are not mutually exclusive but entwined like mother and daughter, sharing the same space of fiction and faction, disturbing ideas and harsh experiences. Through the very legacy of the myth, O'Rourke explores what makes us human and dependent on both philosophical concepts and everyday habits, trying to poeticise the (im)possibility of experiencing the present moment and its artistic potency embodied in, for instance, Picasso's lover's grandmother and other "people whose stories I learn in books". O'Rourke Demeter is omnipotent in her ability to comprehend and rationalise her and Persephone's ambivalent position within a large web of human relations that have existed since the very inception of the myth. While the casually dressed daughter's body and her "hair sticking out" signify the concreteness of contemporary reality, the play of presence and absence seems to re-focus from Persephone's dubious constancy in Demeter's life to "external things: the sky, a piece of grass, a smell" that furthermore lose their contours, becoming colours in a painting that preserves them from oblivion. Artistic and speaking from her own accumulated experience, the Paris Demeter represents a today's multitasking mother whose Persephone is just one of her many preoccupations that comprise a woman's identity in the fast-changing world of instant and simultaneous deaths and revivals. However, it seems that existing and novel versions of the Demeter-Persephone myth are needed more than ever. In their overview of British women's poetry written between 1945 and 1980, Dowson and Entwistle acknowledge the visibility of "emblematic figures of subversive female powers" along with "deities or classical characters like Penelope, Persephone and Eurydice", whose presence signals "the potential of the female imagination" (Dowson and Entwistle, 2005, p. 103). The subsequent DemeterPersephone poems created at the intersection of two centuries, at 
least the ones mentioned in this article, continue to draw on the potential of the female imagination to verbalise and conceive multiple links in the myth-inspired matrilineal networks that are increasingly yet insufficiently reshaping human relations. While the ancient myth and its appropriations "help to explain the relationship between mythic patterns and women's experiences" (Theodorakopoulos, 2012, p. 160), they perhaps still avoid a more direct engagement with Demeter's seemingly decreasing powers of agency and Persephone's abused body, particularly if we agree with the statement that "the female body in crisis is a metonym for larger political crisis" (Gill, 2007, p. 134).

REFERENCES Boland, E. (2008). New Collected Poems. New York: W. W. Norton and Company.

Boland, E. (1995). Object Lessons: the life of the woman and the poet in our time. New York: W.W. Norton \& Company.

Boland, E. and Schmidt, E. (2001). Where Poetry Begins: Eaven Boland in Conversation. Retrieved from https://www.poets.org/poetsorg/text/wherepoetry-begins-eavan-boland-conversation

Dowson, J. and Entwistle, A. (2005). A History of Twentieth-Century British Women's Poetry. Cambridge: Cambridge University Press.

Duffy, C.A. (2001). The World's Wife. New York: Farrar, Straus and Giroux.

Enemark, N. (2016). Antiquarian Magic: Jane Harrison's Ritual Theory and Hope Mirrlees's Antiquarianism in Paris. In: E. Anderson, A. Radford, and H. Walton (Eds.), Modernist Women Writers and Spirituality: A Piercing Darkness (115-134). London: Palgrave Macmillan.

Gill, J. (2007). Women's Poetry. Edinburgh: Edinburgh University Press.

Hirsch, M. (1989). The Mother/Daughter Plot - Narrative, Psychoanalysis, Feminism, Bloomington and Indianapolis: Indiana University Press.

House, V. (2014). Medea's Chorus: Myth and Women's Poetry Since 1950. New York: Peter Lang's Publishing.

Fainlight, R. (1997). Sugar-Paper Blue. Newcastle upon Tyne: Bloodaxe Books.

Norton, J. R. (2016). The Demeter-Persephone Myth as Writing Ritual in the Lives of Literary Women. Newcastle upon Tyne: Cambridge Scholar Publishing.

o'Rourke, M. (2013). Demeter in Paris. Retrieved from https://www.po ets.org/poetsorg/poem/demeter-paris

Ostriker, A. (2009). The Book of Seventy. Pittsburg, Pa.: University of Pittsburg Press. 
Ostriker, A. S. (1986). Stealing the Language: The Emergence of Women's Poetry in America. London: Beacon Press.

Rich, A. (1977). of Woman Born: Motherhood as Experience and Institution. New York: Bantam Books.

Rich, A. (1995). On Lies, Secrets, and Silence: Selected Prose 1966-1978. New York: W.W. Norton \& Company.

Theodorakopoulis, E. (2012). Women's writing and the classical tradition. Classical Reception Journal, 4(2), 149-162.

ТАТЈАНА П. БИЈЕЛИЋ

УНИВЕРЗИТЕТ У БАЬОЈ ЛУЦИ

ФИЛОЛОШКИ ФАКУЛТЕТ

ДЕПАРТМАН ЗА ЕНГЛЕСКИ ЈЕЗИК И КњИЖЕВНОСТ

РЕЗИМЕ

\section{ИЗЛАЗАК ИЗ ПОДЗЕМЉА: РЕФЛЕКСИЈЕ МИТА О ДЕМЕТРИ И ПЕРСЕФОНИ У ШЕСТ САВРЕМЕНИХ ПЈЕСНИЧКИХ ТЕКСТОВА}

Полазећи од чињенице да је древни мит о Демери и Персефони не само један од најстаријих и најзначајнијих митова о односу мајке и кћерке него и најчешће препричана и ревидирана архетипска прича у оквирима савремене женске књижевности, ауторка овог рада настојала је да укаже на улогу овог мита у постављању одговарајућег интерпретацијског контекста женског искуства, што даје додатну димензију тумачењу савременог пјесничког израза. Циљ рада је да укаже на разноврсност пјесничких стратегија обраде мита илустровањем дискусије о положају савремене Деметре унутар друштвених релација моћи, гдје Персефонино тијело представља објекат и локус антагонизама, али и еманципован простор који утиче на динамику односа мајке и ћерке, као и на мањак или интензивирање женске солидарности. Кроз анализу пјесама шест савремених англоамеричких пјесникиња (Фејнлајт, Боланд, Дафи, Острикер и О’Рорк) истраживале су се репрезентације трансформације Деметриних моћи, од божанских до секуларних, као и фрагментације њених свакодневних искустава које су настале на основу објективације женског тијела и све замршенијег пута према регенерацији коју заговара мит.

КљУчнЕ РЕчи: Деметра, Персефона, мит, савремена женска поезија. 
Овај чланак је објављен и дистрибуира се под лиценцом Creative Commons Ауторство-Некомерцијално Међународна 4.0 (СC BY-NC 4.0 |

https://creativecommons.org/licenses/by-nc/4.0/).

This paper is published and distributed under the terms and conditions of the Creative Commons Attribution-NonCommercial International 4.0 licence (CC BY-NC 4.0 | https://creativecommons.org/licenses/by-nc/4.0/). 